\title{
Perancangan Sistem Informasi Posyandu Sebagai Upaya Digitalisasi Data Posyandu di UPTD Puskesmas II Dinas Kesehatan Kecamatan Denpasar Timur
}

\author{
Putu Ika Farmani, I Nyoman Mahayasa Adiputra, Putu Ayu Laksmini \\ Program Studi Manajemen Informasi Kesehatan Fakultas Ilmu-ilmu Kesehatan Universitas Bali Internasional, Bali, Indonesia \\ Jl. Seroja Gg Jeruk, Denpasar Utara -Bali 80114 \\ Korespondensi E-mail: ikafarmani@,iikmpbali.ac.id
}

Submitted: 6 Desember 2021, Revised: 19 Desember 2021, Accepted: 24 Desember 2021

\begin{abstract}
Maternal mortality and stunting descent acceleration is one of effort to increase quality and competitive buman resources. Posyandu become one of the efforts that can reduce these two indicators through activities that involve the community. Therefore, the quality and accuracy of recording and reporting posyandu data is an important thing. This study aims to design a toddler Posyandu information system as an effort to overcome recording, reporting, and digitizing posyandu data problems. Case study research was design at the UPTD of PHC II East Denpasar Health Service used to design a web-based information system with Waterfall method. Primary data was obtained through interviews with PHC officers and secondary data by reviewing recording and reporting documents. The design stages included defining requirements, system design, implementation and unit testing, and integration and system testing. Total of 240 toddler visited data from posyandu were used for the system testing. The result show that the posyandu information system design help cadres to reduce repetitive data recording incident, can increase the uniformity and punctuality of reporting by cadres, help PHC officers to integrate posyandu data that can be used for nutritional surveillance reporting, and also store the activities posyandu data in digital form. The conclusion of this study is the posyandu information system can be a recording and reporting solution by cadres and PHC officers.
\end{abstract}

Keywords: posyandu, information system, digitalizing, design

\begin{abstract}
Abstrak
Percepatan penurunan kematian ibu dan stunting menjadi salah satu upaya meningkatkan sumber daya manusia berkualitas dan berdaya saing. Posyandu menjadi salah satu upaya yang dapat menurunkan dua indikator tersebut melalui kegiatan yang melibatkan masyarakat. Oleh karena itu kualitas dan ketepatan pencatatan dan pelaporan data posyandu menjadi hal yang penting. Penelitian ini bertujuan merancang sistem informasi posyandu balita sebagai upaya mengatasi permasalahan pencatatan, pelaporan, dan digitalisasi data posyandu. Rancangan penelitian studi kasus di UPTD Puskesmas II Dinas Kesehatan Denpasar Timur mengunakan perancangan sistem informasi berbasis web dengan metode $W$ aterfall. Data primer diperoleh melalui wawancara dengan petugas puskesmas dan data sekunder dengan menelaah dokumen pencatatan dan pelaporan. Tahapan perancangan meliputi mendefinisikan kebutuhan, desain sistem, implementasi dan pengujian unit, dan integrasi serta pengujian sistem. Sebanyak 240 data kunjungan balita dari posyandu digunakan untuk uji coba sistem. Hasil penelitian menunjukkan perancangan sistem informasi posyandu membantu kader untuk mengurangi kegiatan pencatatan data yang berulang-ulang, dapat meningkatkan keseragaman dan ketepatan waktu pelaporan oleh kader, membantu petugas puskesmas untuk mengintegrasikan data posyandu yang bisa digunakan untuk pelaporan surveilans gizi, serta menyimpan data kegiatan posyandu dalam bentuk digital. Simpulan dalam penelitian ini adalah sistem informasi posyandu dapat menjadi solusi pencatatan dan pelaporan oleh kader dan petugas puskesmas.
\end{abstract}

Kata Kunci: posyandu, sistem informasi, digitalisasi, perancangan

\section{Pendahuluan}

Indonesia sebagai bangsa yang besar tentunya memiliki tujuan nasional yang diwujudkan melalui berbagai pembangunan nasional. Salah satu dari agenda pembangunan nasional bangsa Indonesia dalam RPJM (Rencana Pembangunan Jangka Menengah) 2020-2024 yaitu pemenuhan layanan dasar. Pemenuhan layanan dasar yang dimaksud pada RPJM beberapa diantaranya adalah penurunan angka stunting (pendek dan sangat pendek) pada balita, penurunan angka wasting (kurus dan sangat kurus) pada balita, penurunan angka kematian ibu, penurunan angka kematian bayi, peningkatan prevalensi 
pemakaian kontrasepsi cara modern, serta peningkatan persentase imuniasi dasar lengkap pada anak usia 12-23 bulan (1).

Menurut Riskesdas 2018, prevalensi stunting pada balita menunjukkan angka yang masih tinggi yaitu 30,8\%, sedangkan target prevalensi stunting RPJM 2020-2024 adalah 19\%. Sedangkan menurut Riskesdas 2018 prevalensi wasting pada balita menunjukkan angka yang masih tinggi pula yaitu 10,2\%, sementara target prevalensi stunting RPJM 2020-2024 adalah 7\% (1). Begitu halnya dengan angka kematian ibu pada tahun 2015 dalam SUPAS (Survei Penduduk Antar Sensus) tergolong masih tinggi yaitu 305 per 100.000 kelahiran hidup, sedangkan target prevalensi stunting RPJM 2020-2024 adalah 183 per 100.000 kelahiran (1). Sedangkan untuk beberapa angka layanan dasar lainnya mesti ditingkatkan seperti prevalensi pemakaian kontrasepsi cara modern (SDKI (2017) menunjukkan angka 57,2) sementara target RPJM 63,4) dan persentase imunisasi dasar lengkap pada anak usia 12-23 bulan (Menurut Riskesdas 2018 57,9\%, target RPJM 80\%) (1).

Guna mewujudkan tujuan pembangunan nasional yang telah dipaparkan di atas maka kehadiran Posyandu di masyarakat menjadi sangat penting. Posyandu merupakan salah satu bentuk upaya kesehatan bersumber daya masyarakat yang dikelola dari, oleh, untuk dan bersama masyarakat, guna memberdayakan masyarakat dan memberikan kemudahan kepada masyarakat dalam memperoleh pelayanan kesehatan bagi ibu, bayi dan anak balita (2). Posyandu memiliki beberapa program yang berhubungan dengan tujuan nasional seperti program kesehatan ibu dan anak, keluarga berencana, imunisasi, dan gizi (2). Berdasarkan hasil wawancara dengan pemegang Program Gizi di UPTD Puskesmas II Dinas Kesehatan Denpasar Timur, diketahui bahwa sistem pencatatan seluruh kegiatan posyandu masih menggunakan metode manual, sehingga memerlukan waktu yang lebih lama baik dalam menangani kunjungan pasien, maupun dalam pembuatan laporan hasil kunjungan. Selain itu dengan adanya penerapan e-PPGBM pada program gizi di UPTD Puskesmas II Dinas Kesehatan Kecamatan Denpasar Timur yang menggunakan sumber data dari kegiatan posyandu menyebabkan ada lebih dari satu kali kegiatan rekapitulasi data untuk memenuhi kebutuhan kedua program ini. Mengacu pada permasalahan yang terjadi pada sistem pencatatan Posyandu di Desa Penatih Denpasar Timur, serta melihat semakin berkembangnya teknologi informasi di era modern yang mempermudah pengguna untuk menerima informasi dengan cepat, maka dilakukan penelitian dengan tujuan merancang sistem informasi posyandu sebagai upaya untuk mengatasi permasalahan dalam pencatatan, pelaporan, dan digitalisasi data posyandu.

\section{Metode Penelitian}

Rancangan penelitian ini merupakan studi kasus yang fokus pada kasus dalam kegiatan posyandu balita yang dilakukan di UPTD Puskesmas II Dinas Kesehatan Denpasar Timur. Perancangan sistem posyandu berbasis web dibuat berdasarkan analisis kebutuhan yang ada di lapangan dengan menerapkan metode Waterfall. Metode waterfall adalah salah satu model pengembangan sistem informasi yang sistematik dan sekuensial (3). Adapun tahapan perancangan sistem informasi posyandu yang dilakukan adalah mendefinisikan kebutuhan, desain sistem, implementasi dan pengujian unit, dan integrasi serta uji coba sistem. Data yang digunakan yaitu data primer yang diperoleh dari hasil wawancara dengan Pemegang Program Gizi di UPTD Puskesmas II Dinas Kesehatan Denpasar Timur dan data sekunder berupa data rekapitulasi SIP (Sistem Informasi Posyandu), rekapitulasi laporan Pemegang Program Gizi, Peraturan Menteri Kesehatan Republik Indonesia Nomor 14 Tahun 2019 tentang Pelaksanaan Teknis Surveilans Gizi, dan Peraturan Menteri Kesehatan Republlik Indonesia Nomor 2 Tahun 2020 Tentang Standar Antropometri Anak. Penelitian diawali dengan mengidentifikasi kebutuhan sistem dari sisi kader dan pemegang program gizi, perancangan sistem informasi posyandu, dan uji coba setiap fungsi-fungsi dalam sistem informasi posyandu dengan menggunakan 240 data kunjungan dari kegiatan posyandu yang dilaksanakan di Desa Penatih Dangin Puri. 


\section{Hasil dan Pembahasan}

Posyandu balita merupakan salah satu bentuk kegiatan pemberdayaan masyarakat yang penyelenggaraanya berada di bawah kelurahan atau desa setempat. UPTD Puskesmas II Dinas Kesehatan Kecamatan Denpasar Timur bertugas untuk membina dan mendampingi kader posyandu dalam menjalankan kegiatan di lapangan sampai dengan pembuatan laporan oleh kader. Terdapat 60 posyandu dengan jumlah masing-masing kader pada setiap posyandu rata-rata sebanyak lima orang di mana 51 posyandu dengan strata madya dan 9 posyandu dengan strata purnama.

Sistem pencatatan kegiatan posyandu balita oleh kader yang sedang berjalan masih bersifat manual, dimana kader menggunakan sebuah buku register yang dikenal dengan SIP dan pengisian hasil pengukuran berat badan dan tinggi badan pada buku KIA/KMS balita. Sedangkan untuk pelaporan kegiatan posyandu ke pihak puskesmas kader harus mengisi formulir yang diberikan oleh Petugas Program Gizi yang berisi tentang nama balita, tanggal lahir, jenis kelamin, nama orang tua, nomor telepon orang tua, hasil pengukuran (berat badan dan tinggi badan), dan keterangan dengan cara merekapitulasi data dari buku SIP setiap bulan serta merekapitulasi hasil penimbangan posyandu ke dalam variabelvariabel pemantauan pertumbuhan balita menurut balok SKDN. Selanjutnya Petugas Program Gizi menganalisis pemantauan pertumbuhan balita dengan menganalisis indikator-indikator surveilans gizi yang terdiri dari persentase $\mathrm{D} / \mathrm{S}$, persentase $\mathrm{K} / \mathrm{S}$, persentase $\mathrm{N} / \mathrm{D}^{\prime}$, persentase $2 \mathrm{~T} / \mathrm{D}$ ', dan status gizi balita.

Kelemahan dari sistem yang sedang berjalan antara lain:

1. Data balita masih disimpan secara manual oleh kader sehingga sering mengalami kehilangan data dan sulit untuk melakukan pencarian data

2. Kader melakukan penulisan data yang sama berulang kali untuk pencatatan di Buku SIP dan laporan bulanan ke pemegang Program Gizi

3. Tidak semua kader memiliki tingkat kelengkapan dan ketepatan waktu pencatatan dan pelaporan yang sama

4. Keterbatasan akses data oleh pemegang Program Gizi selaku pembina kegiatan posyandu dari puskesmas sehingga harus menunggul laporan manual oleh kader terkumpul dulu oleh kader yang akan direkapitulasi kembali menjadi laporan pemantauan pertumbuhan balita per wilayah

\section{Definisi Kebutuhan}

Definisi kebutuhan pada penelitian ini dilakukan dengan wawancara pada seorang yaitu Pemegang Program Gizi yang bertanggung jawab dalam mendampingi kegiatan posyandu balita di wilayah kerja UPTD Puskesmas II Dinas Kesehatan Kecamatan Denpasar Timur serta studi literatur tentang pedoman penetapan status gizi balita. Hasil dari definisi kebutuhan Sistem Informasi Posyandu ditampilkan pada Tabel 1. Berdasarkan definisi kebutuhan yang perlu dilakukan pendekatan lebih lanjut kepada pengguna yaitu tentang pembuatan cohort perkembangan balita per bulan, laporan hasil penimbangan posyandu oleh kader setiap bulan, dan laporan pemantauan pertumbuhan balita dengan metode balok SKDN yang menyajikan tentang pencapaian kegiatan posyandu dan status gizi balita. 
Tabel 1.

Kebutuhan Data Sistem Informasi Posyandu (SIP)

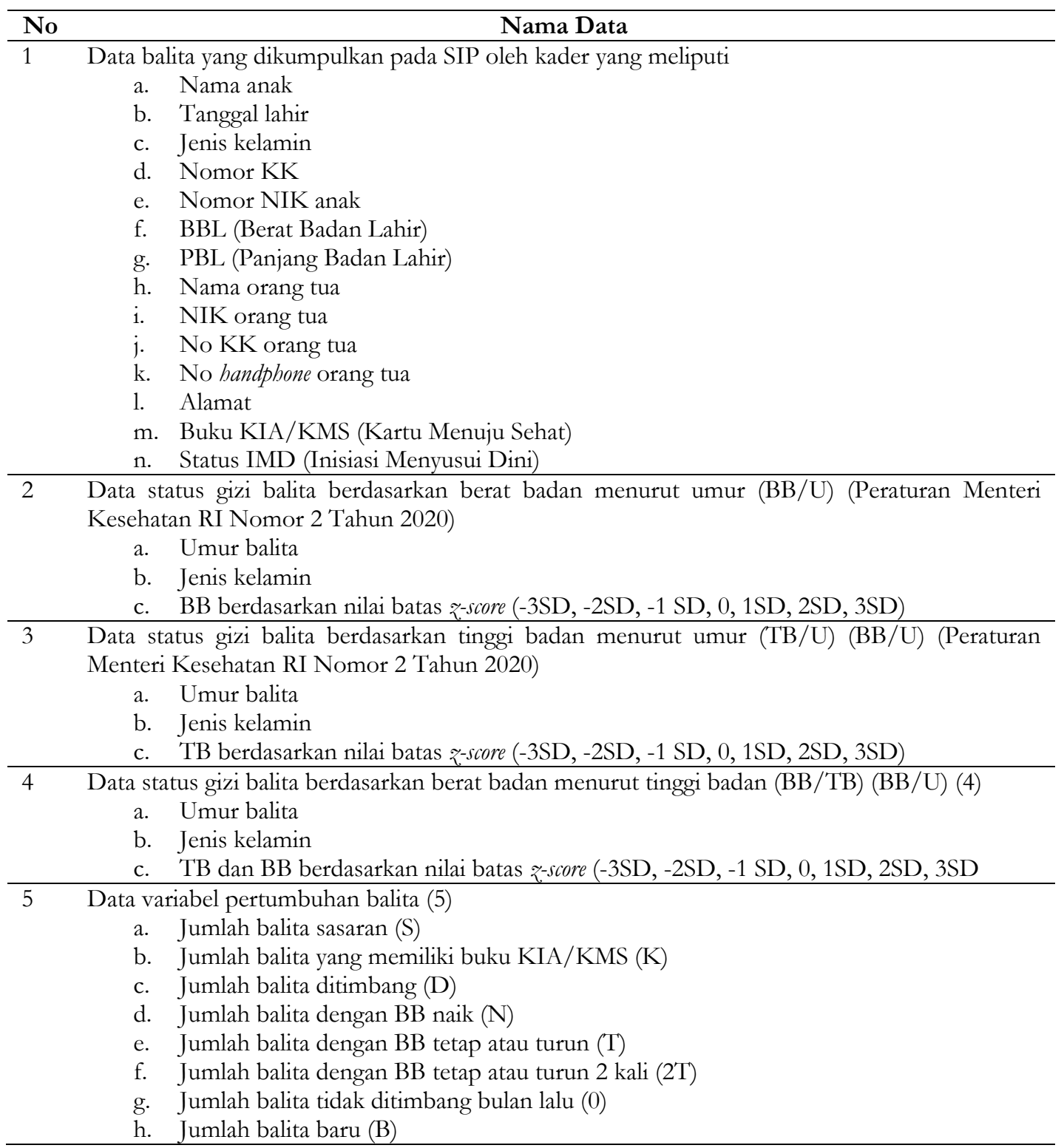

\section{Desain Sistem}

Perancangan sistem informasi posyandu dilaksanakan dengan model use case diagram dan perancangan output sebagai berikut.

1. Use Case Diagram dan Naratif

Penjelasan masing-masing fungsional dari sistem informasi posyandu dapat dijabarkan pada use case diagram pada Gambar 1. 


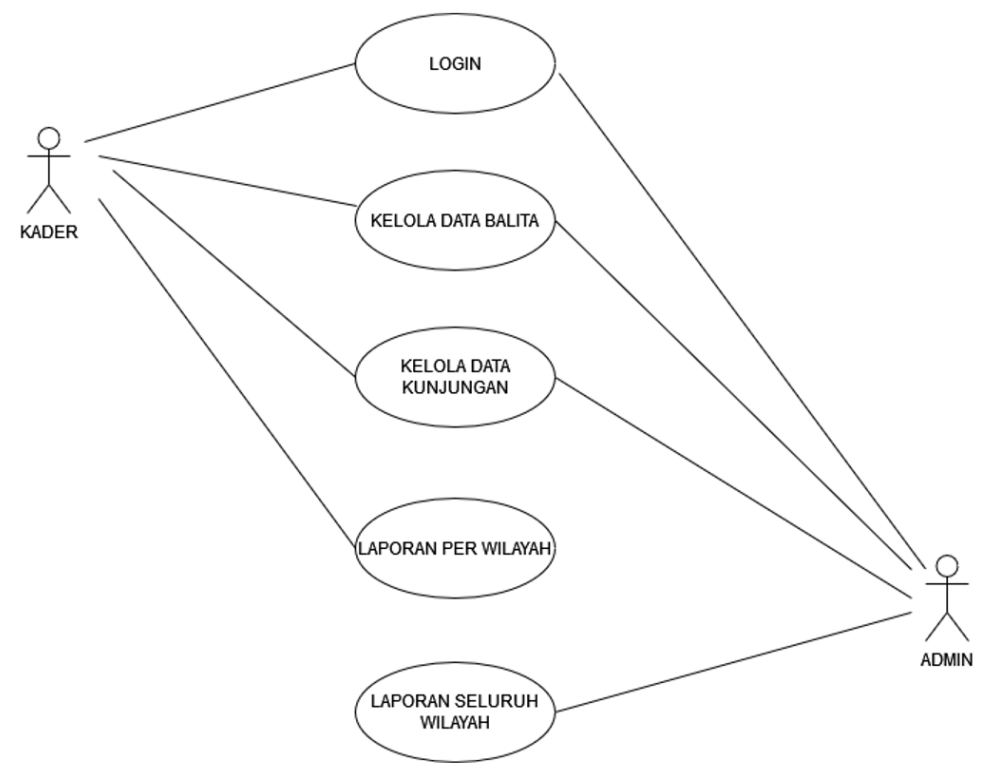

Gambar 1.

Use Case Diagram Sistem Informasi Posyandu

Pada use case diagram diketahui terdapat dua pengguna yang berperan dalam menjalankan sistem informasi posyandu yang dirancang yaitu kader dan petugas admin sistem (petugas pemegang program gizi). Setiap pengguna ini harus memiliki username dan password sebagai prasyarat akses ke sistem informasi posyandu. Admin dalam hal ini bertugas untuk mendaftarkan setiap kader agar memiliki akses terhadap sistem. Kader memiliki akses untuk melakukan kegiatan login, pengelolaan data balita dan pengelolaan data kunjungan di wilayah kerja kader. Sedangkan untuk admin memiliki akses dalam login, pengelolaan data balita, pengelolaan data kunjungan, dan laporan kegiatan posyandu seluruh wilayah.

2. Hasil Tampilan Input

Adapun perancangan imput yang digunakan pada sistem informasi posyandu ditampilkan pada Gambar 2.

a. Home

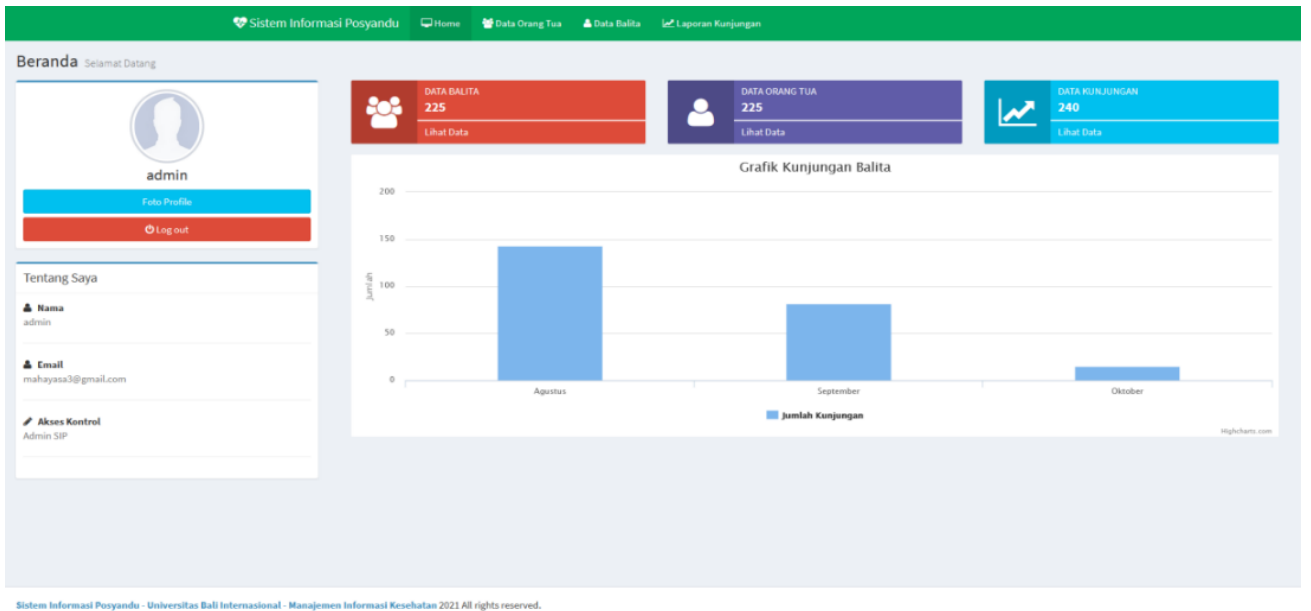

Gambar 2.

Tampilan Home Sistem Informasi Posyandu

Pada bagian Home menampilkan nama petugas, jumlah total data balita, data orang tua, data kunjungan, serta grafik kunjungan balita berdasarkan bulan yang tercatat di sistem. 
b. Login

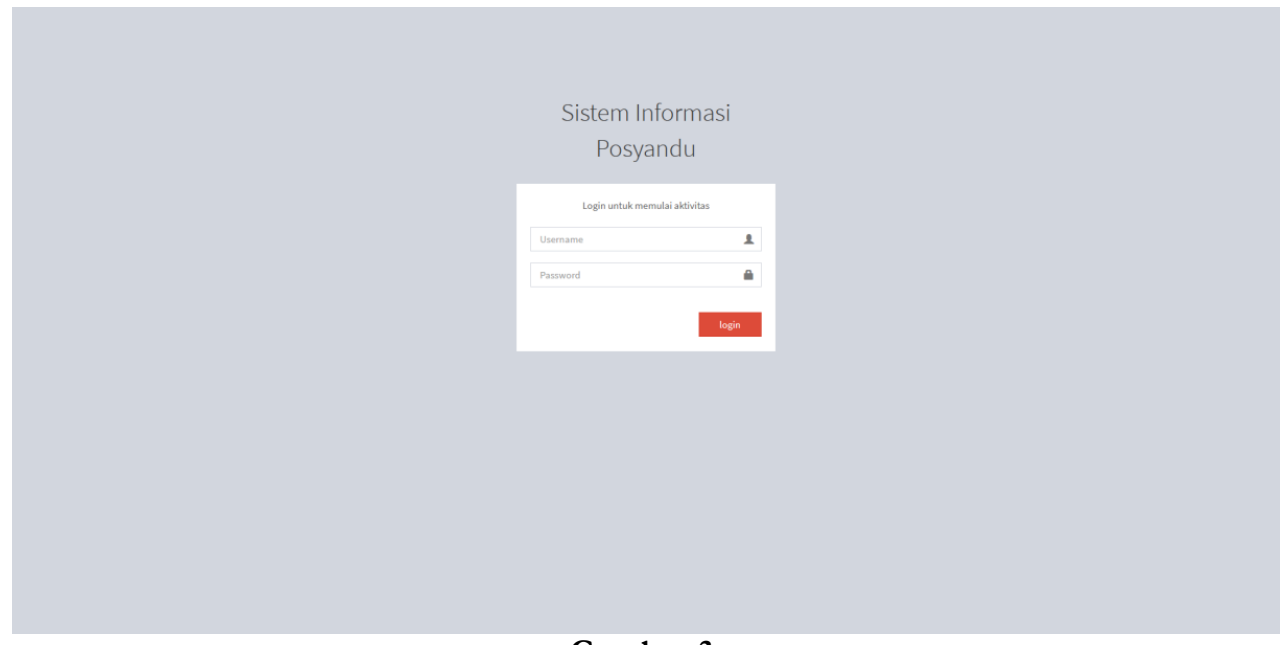

Gambar 3.

Tampilan Halaman Login

Halaman login pada sistem memuat tentang username dan password yang harus diisi oleh setiap pengguna sistem (kader posyandu dan admin) yang sudah didaftarkan oleh pihak admin (Gambar 3).

c. Tambah data orang tua

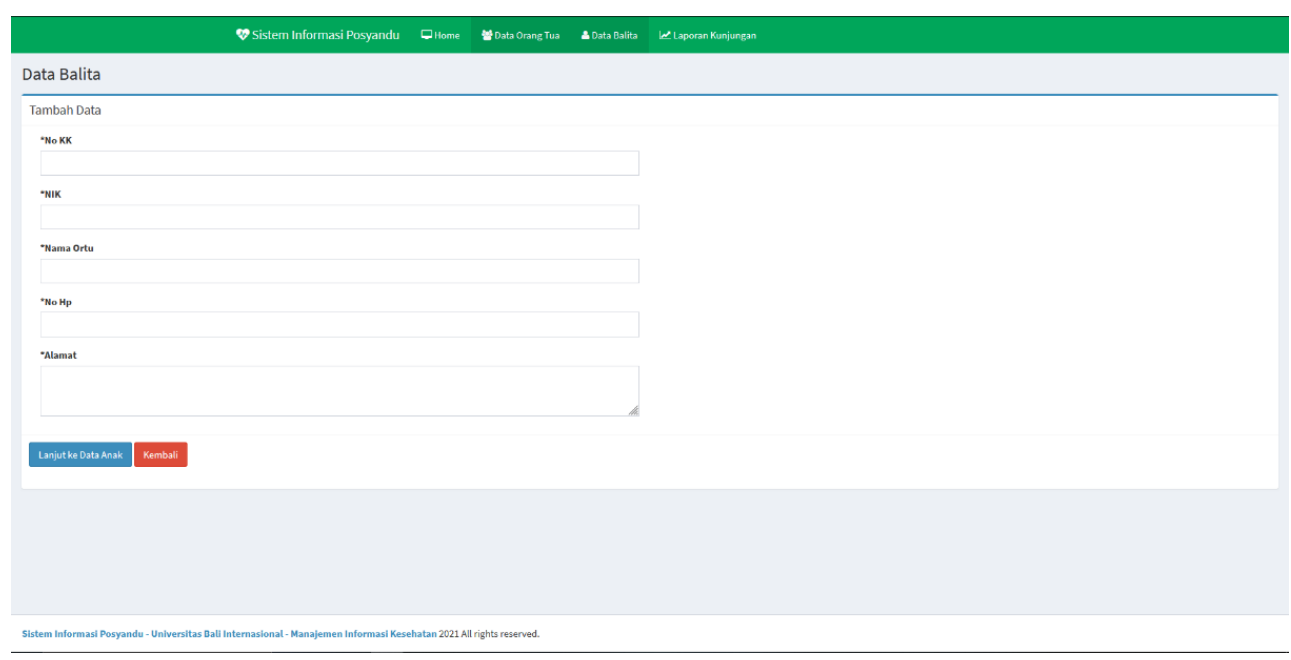

\section{Gambar 4.}

Tampilan Halaman Tambah Data Orang Tua

Halaman tambah data orang tua (Gambar 4) berisi informasi tentang No KK, NIK, nama orang tua, nomor handphone, dan alamat. 
d. Tambah data balita

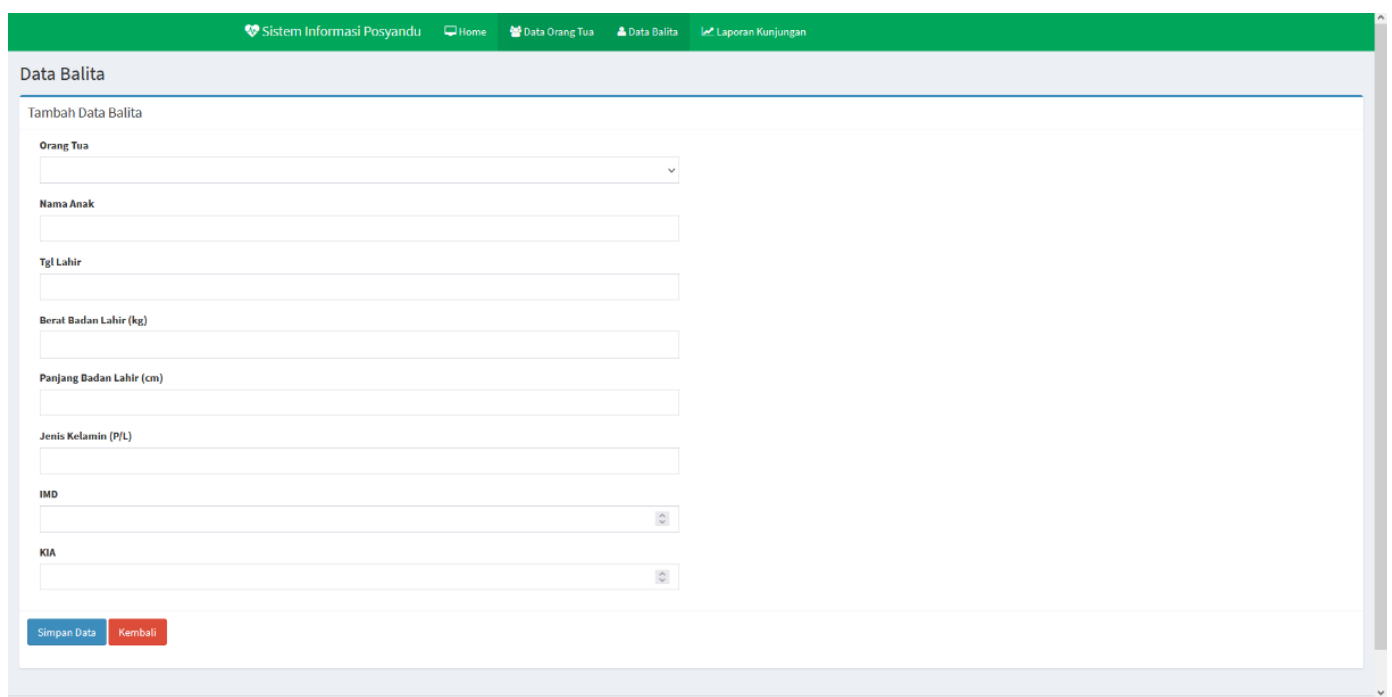

\section{Gambar 5.}

Tampilan Halaman Tambah Data Balita

Halaman tambah data balita (Gambar 5), merupakan halaman untuk mengisi identitas balita yang baru pertama kali berkunjung ke posyandu yang berisi informasi tentang nama orang tua, nama anak, tanggal lahir, BB lahir, panjang badan lahir, jenis kelamin, status IMD (Inisiasi Menyusui Dini), dan kepemilikan buku KIA.

e. Tambah kunjungan balita

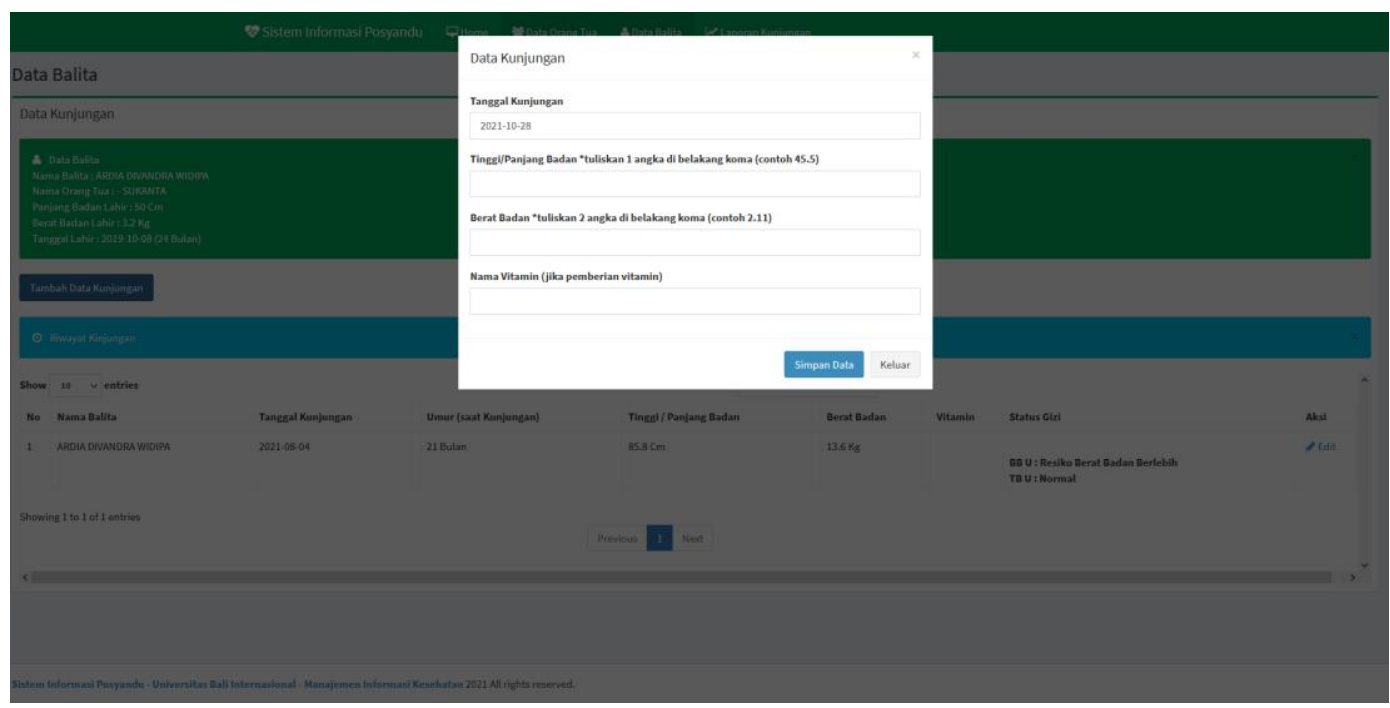

Gambar 6.

Tampilan Halaman Kunjungan Balita

Halaman kunjungan balita (Gambar 6) berisi tentang data per kedatangan balita ke posyandu yang terdiri dari tanggal kunjungan, hasil pengukuran saat kunjungan yang terdiri dari tinggi atau panjang badan, berat badan, dan nama vitamin (jika ada pemberian vitamin). 
3. Perancangan Output

Secara umum output dari sistem informasi posyandu ini meliputi tiga hal yaitu daftar kunjungan balita, rekapitulasi pertumbuhan balita, dan pemantauan pertumbuhan balita. Adapun perancangan output yang dihasilkan oleh sistem informasi posyandu adalah sebagai berikut:

a. Daftar kunjungan balita

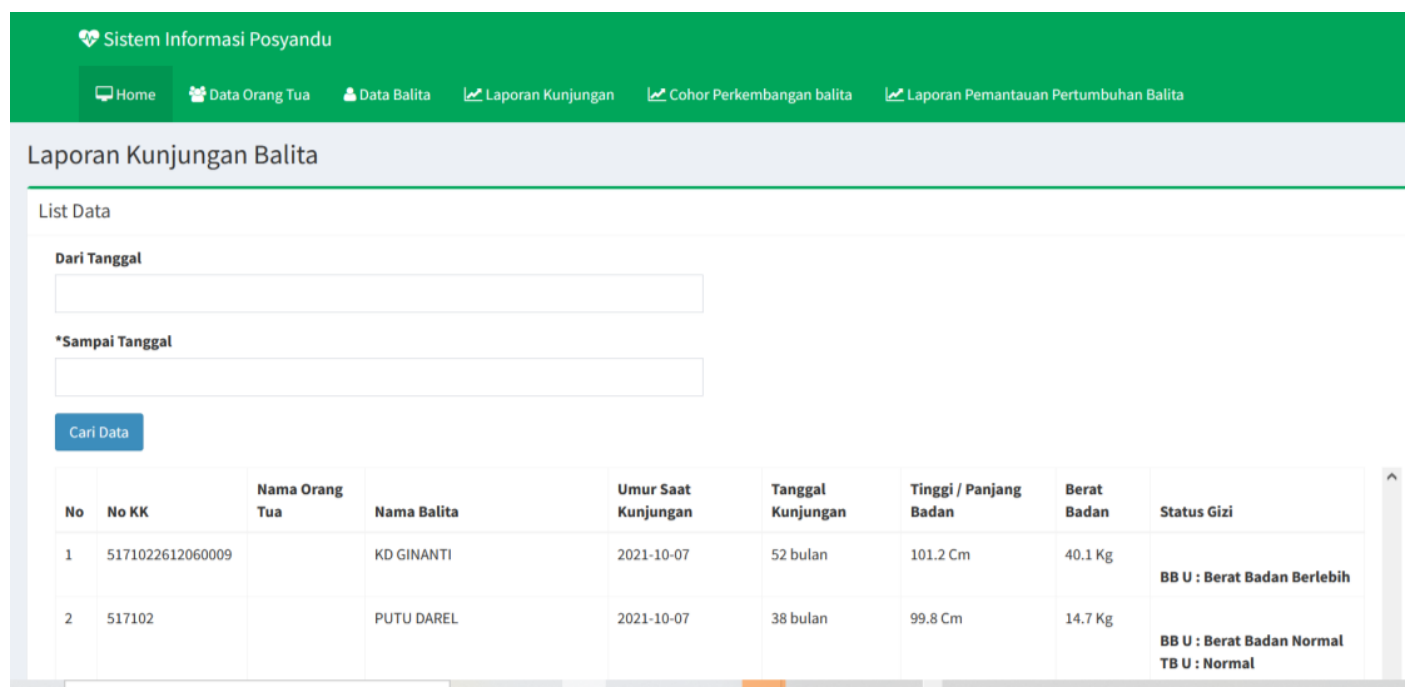

Gambar 7.

Tampilan Daftar Kunjungan Balita

Output pertama yaitu daftar kunjungan balita (Gambar 7) menampilkan semua data kunjungan balita pada sistem yang bisa dilakukan proses pencarian berdasarkan periode waktu tertentu.

b. Cohort perkembangan balita

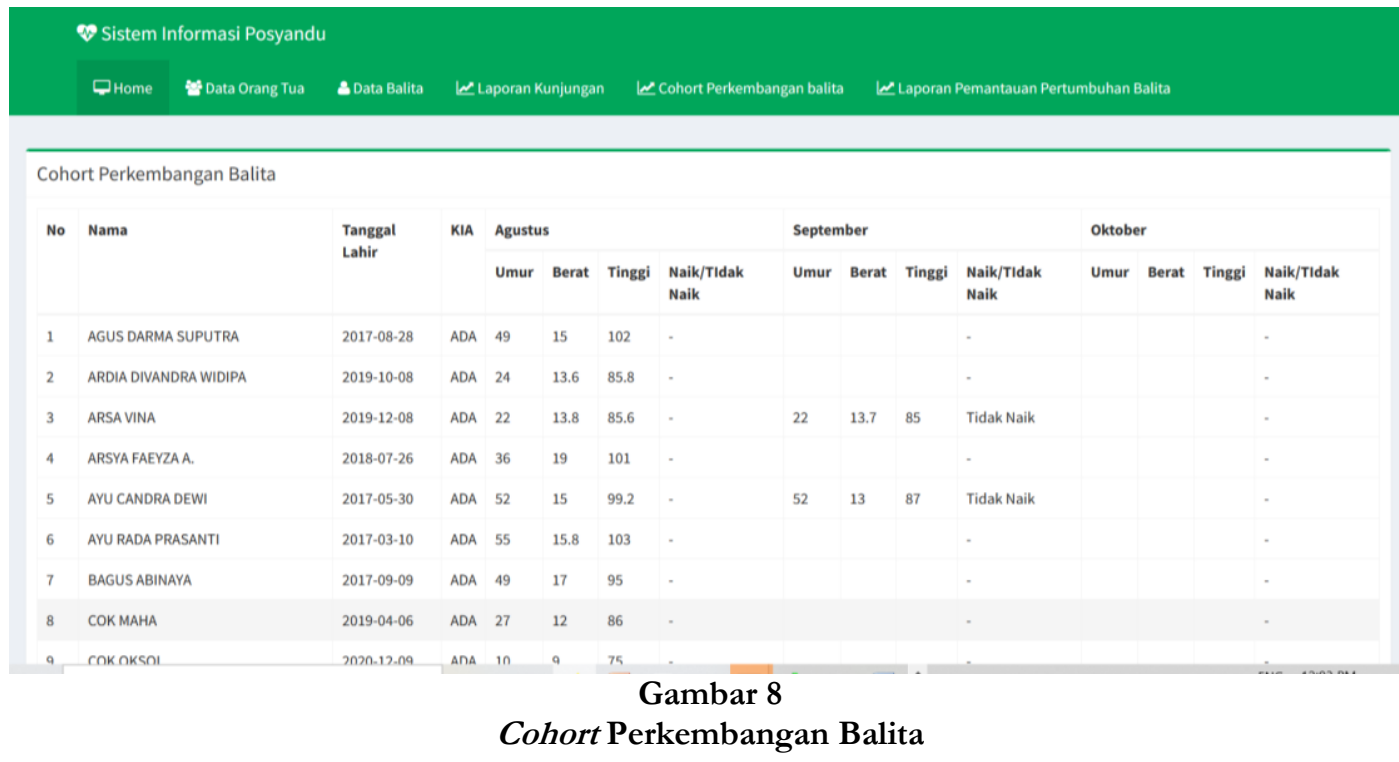

Output kedua dari sistem yaitu cohort perkembangan balita (Gambar 8) yang menampilkan nama balita, tanggal lahir, kepemilikan KIA, perubahan umur, berat badan, tinggi, dan status 
perubahan berat badan yang diukur per bulan. Output ini bisa menggantikan buku register kader posyandu yang selama ini dicatat secara manual pada sebuat buku berukuran folio.

c. Pemantuan pertumbuhan balita

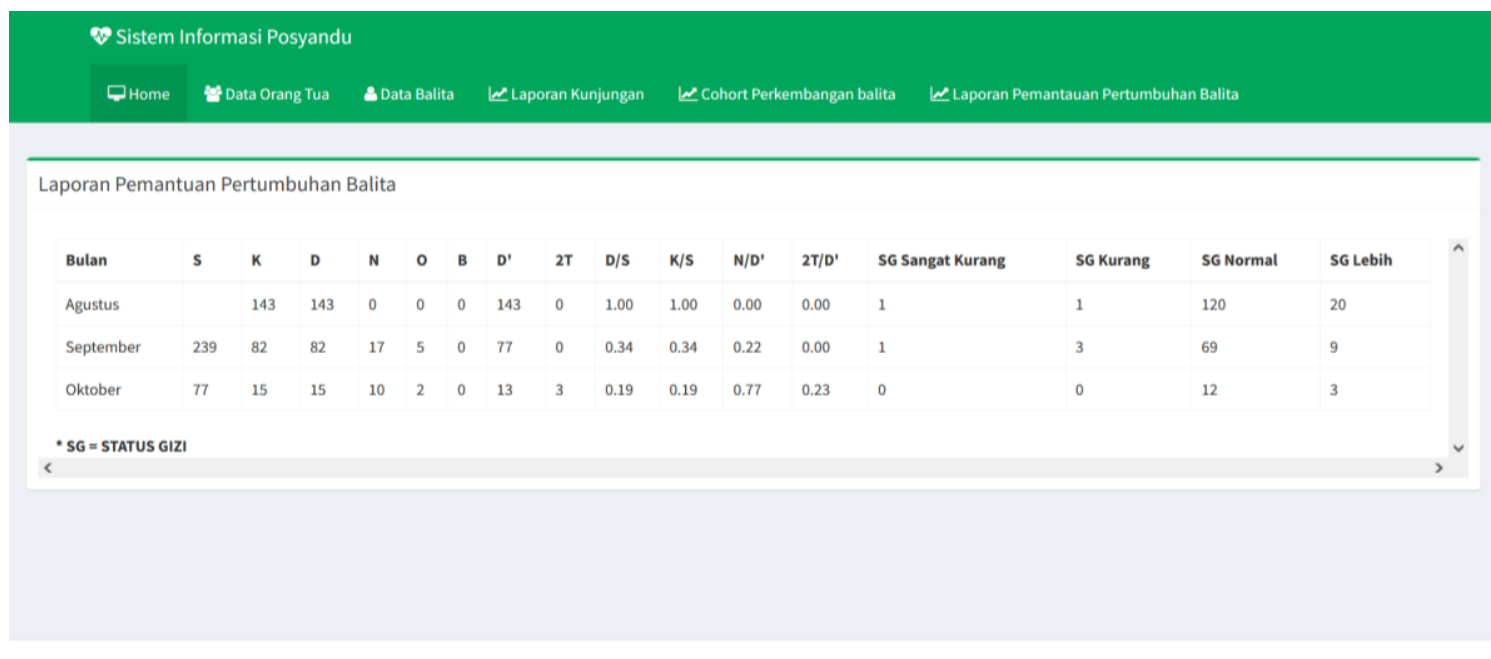

Gambar 9.

Format Laporan Pemantauan Pertumbuhan Balita

Laporan pemantauan pertumbuhan balita (Gambar 9) menampilkan hasil analisis kinerja posyandu per bulan berdasarkan indikator balok SKDN dengan indikator kinerja $\mathrm{D} / \mathrm{S}, \mathrm{K} / \mathrm{S}$, N/D', 2T/D, dan status gizi balita.

Perancangan sistem informasi posyandu balita di wilayah kerja UPTD Puskesmas II Dinas Kesehatan Denpasar Timur dibuat menggunakan metode waterfall berdasarkan analisis kebutuhan. Perancangan sistem informasi yang dikembangkan adalah berbasis web di mana terdapat 3 kegiatan utama yaitu input, proses dan output. Beberapa penelitian terdahulu tentang perancangan sistem informasi pernah dilakukan namun memiliki cakupan kegiatan posyandu yang beragam seperti halnya sistem informasi posyandu KIA berbasis web (E-Posyandu) yang dikembangkan di posyandu mekarsari RW.VI Kelurahan Pedalangan Semarang, pengembangan sistem informasi posyandu KIA berbasis local host dan web, perancangan sistem informasi posyandu KIA berbasis web android, perancangan sistem informasi Posyandu Pepaya Purwokerto untuk balita serta ibu hamil, pengembangan aplikasi Pos Yandu berbasis web untuk balita, dan perancangan sistem informasi posyandu untuk menunjang program pendampingan komunitas $(6)(7)(8)(9)(10)$. Namun ada pula penelitian terdahulu yang mengembangkan aplikasi pengolahan data posyandu dengan bahasa pemrograman PHP dan MySQL berdasarkan kebutuhan pihak posyandu dalam mengelola data posyandu di lapangan yang masih menggunakan cara manual $(11,12)(13)(14)$.

Meskipun perancangan atau pengembangan sistem informasi posyandu baik pada penelitian ini maupun penelitian terdahulu memiliki metode dan bentuk sistem informasi yang berbeda, namun semuanya memiliki kesamaan yaitu bertujuan untuk meningkatkan kualitas pencatatan dan pelaporan data posyandu. Apabila dilihat dari sisi fitur sistem informasi ada beberapa perbedaan yang disebabkan oleh jenis posyandu yang dikembangkan misalnya Posyandu KIA, Posyandu Balita, dan lainnya. Di bagian laporan yang dihasilkan pada penelitian ini lebih difokuskan untuk menghasilkan data kunjungan balita, rekapitulasi pertumbuhan balita, dan laporan pemantauan pertumbuhan balita. Pada beberapa penelitian terdahulu tidak ditemukan pelaporan tentang pemantauan pertumbuhan balita yang berpedoman dengan indikator balok SKDN, hal ini mungkin disebabkan ada perbedaan kepentingan palaporan di lapangan. Pembina kader posyandu di UPTD Puskesmas II Dinas Kesehatan Denpasar Timur merupakan seorang petugas Pemegang Program Gizi di mana salah satu indikator program yang dilaporkan rutin yaitu Surveilans Gizi Balita yang sesunggunya data tersebut bisa diperoleh dari kegiatan posyandu. Oleh karena itu bisa dikatakan sistem informasi posyandu yang dikembangkan sudah 
mengintegrasikan kebutuhan Program Gizi yang membutuhkan data posyandu untuk menghitung pencapaian indikator balok SKDN serta mampu memfasilitasi upaya digitalisasi data kegiatan posyandu. Seperti halnya penelitian sistem perancangan sistem informasi posyandu di RW 04 Cipinang Muara ini data-data yang disimpan di dalam database lebih aman dan terstruktur serta pembuatan laporan lebih mudah (15).

Apabila dilihat dari sisi alur sistem informasi posyandu balita sebelum dikembangkan sistem informasi posyandu ini tentunya akan terjadi alur perubahan pencatatan dan pelaporan data posyandu. Kalau sistem sebelumnya mengharuskan kader mencatat data yang sama tiga kali untuk setiap kegiatan posyandu maka dengan adanya sistem informasi posyandu ini kader cukup entri data satu kali saja pada sistem. Hal ini sesuai dengan pernyataan oleh Pragianata (2013) bahwa Dukungan Teknologi Informasi dan Komunikasi (TIK) pengolahan data manual dapat digantikan dengan sistem informasi berbasis Komputer (16). Sistem informasi juga membantu kader untuk mendapatkan catatan cohort kunjungan balita setiap bulan dan membantu membuat rekapitulasi status gizi balita. Selain keuntungan untuk kader, sistem informasi posyandu yang dirancang mempermudahkan Pemegang Program Gizi untuk mengakses data pemantauan pertumbuhan balita berdasarkan balok SKDN. Berdasarkan pemaparan di atas dapat disimpulkan bahwa jika sistem informasi posyandu ini diterapkan sebagaimana mestinya akan memenuhi manfaat dari suatu sistem yaitu meningkatkan efektifitas dan efisiensi suatu kegiatan.

\section{Pengujian Unit dan Integrasi Sistem}

Pengujian pada penelitian ini menggunakan Black Box Testing yang merupakan pengujian yang berfokus pada spesifikasi fungsional dari perangkat lunak, tester dapat mendefinisikan kumpulan kondisi input dan melakukan pengetesan pada spesifikasi fungsional program. Black box testing melakukan pengujian tanpa pengetahuan detil struktur internal dari sistem atau komponen yang dites yang disebut juga sebagai behavioral testing, specification-based testing, input/output testing atau functional testing. Dengan adanya pengujian black box testing ini diharapkan jika ada kesalahan maupun kekurangan di dalam aplikasi dapat segera diketahui sedini mungkin oleh peneliti. Hasil pengujian menggunakan black box pada penelitian ini dapat dilihat pada Tabel 2. Dari hasil pengujan pada Tabel 2 yang berisi hasil pengujian unit dan integrasi sistem terdapat 7 skenario pengujian yang dilakukan dari semua skenario pengujian keseluruhan hasil yang di harapkan pada aplikasi sudah berjalan dengan baik dan memberikan hasil 100\% valid.

\section{Uji Coba Sistem}

Uji coba sistem dilakukan dengan tujuan untuk melihat apakah fungsi-fungsi dari sistem informasi posyandu dapat beroperasi sebagaimana mestinya. Uji coba dilakukan dengan cara memasukkan data kegiatan posyandu balita Desa Penatih Dangin Puri yang terdiri dari posyandu Banjar Buaji, BTN Mertasari, Gunung, Palagiri, dan Bekul. Sebanyak 240 data kunjungan balita dari Bulan Agustus, September, dan Oktober yang digunakan untuk melihat analisis data tehadap pemantauan pertumbuhan balita menurut indikator pencapaian balok SKDN.

Temuan tentang metode pencatatan posyandu yang masih manual dan berulang melakukan rekapitulasi data sejalan dengan pada penelitian terdahulu. Beberapa penelitian tentang posyandu yang dilakukan di Desa Bimomartini, Kecamatan Semarang Selatan, Lasi Kecamatan Canduang, Desa Pagerwejo, dan Kelurahan Dupak juga memperoleh hal yang serupa (6-8,17,18)(13). Padahal pengolahan data secara manual tentu memiliki banyak kekurangan, di samping waktu yang lama, serta tingkat keakuratan dalam input, proses, dan pelaporan data (8). Kendala lainnya dalam pencatatan manual yaitu buku catatan sering rusak, hilang, ganti buku, sulit dibaca, dan sulit mendeteksi perkembangan balita (8) (17).

Sebagian besar kader juga belum menerapkan teknologi dalam pengelolaan data posyandu padahal mereka cukup terbiasa dalam menggunakan handphone dengan fitur android. Seperti pengabadian masyarakat yang dilakukan di Desa Bimomartini menemukan bahwa posyandu di desa tersebut belum memiliki aplikasi berbasis teknologi informasi yang membantu kader dalam melaksanakan pencatatan dan penemuan kembali informasi ibu dan anak yang ditangani akibatnya terjadi kerentanan untuk kehilangan data, kesalahan mencatat, dan tidak dapat dilakukan akses data secara bersama-sama (17). Selain temuan dari sisi kader posyandu, pada penelitian ini juga dilihat dari sisi petugas Pemegang Program Gizi selaku pendamping kader posyandu balita dalam melaksanakan kegiatannya. Temuan yang 
diperoleh yaitu dengan metode pencatatan yang manual, Pemegang Program Gizi juga menghitung capaian pertumbuhan balita berdasarkan wilayah posyandu (desa dan kelurahan) dengan merekapitulasi formulir yang dikumpulkan oleh masing kader posyandu di setiap banjar. Ketidakseragaman pencatatan, ketidaklengkapan data, dan ketepatan waktu pengumpulan laporan secara manual ini menjadi salah satu hambatan untuk Pemegang Program Gizi di puskemas untuk melakukan pengolahan data posyandu yang harus dilakukan setiap bulan. Sistem informasi posyandu ini dapat mengatasi permasalahan ketidakseragaman, ketidaklengkapan, dan ketepatan pengumpulan data yang dilakukan oleh kader posyandu.

Tabel 2.

Hasil Pengujian Unit dan Integrasi Sistem

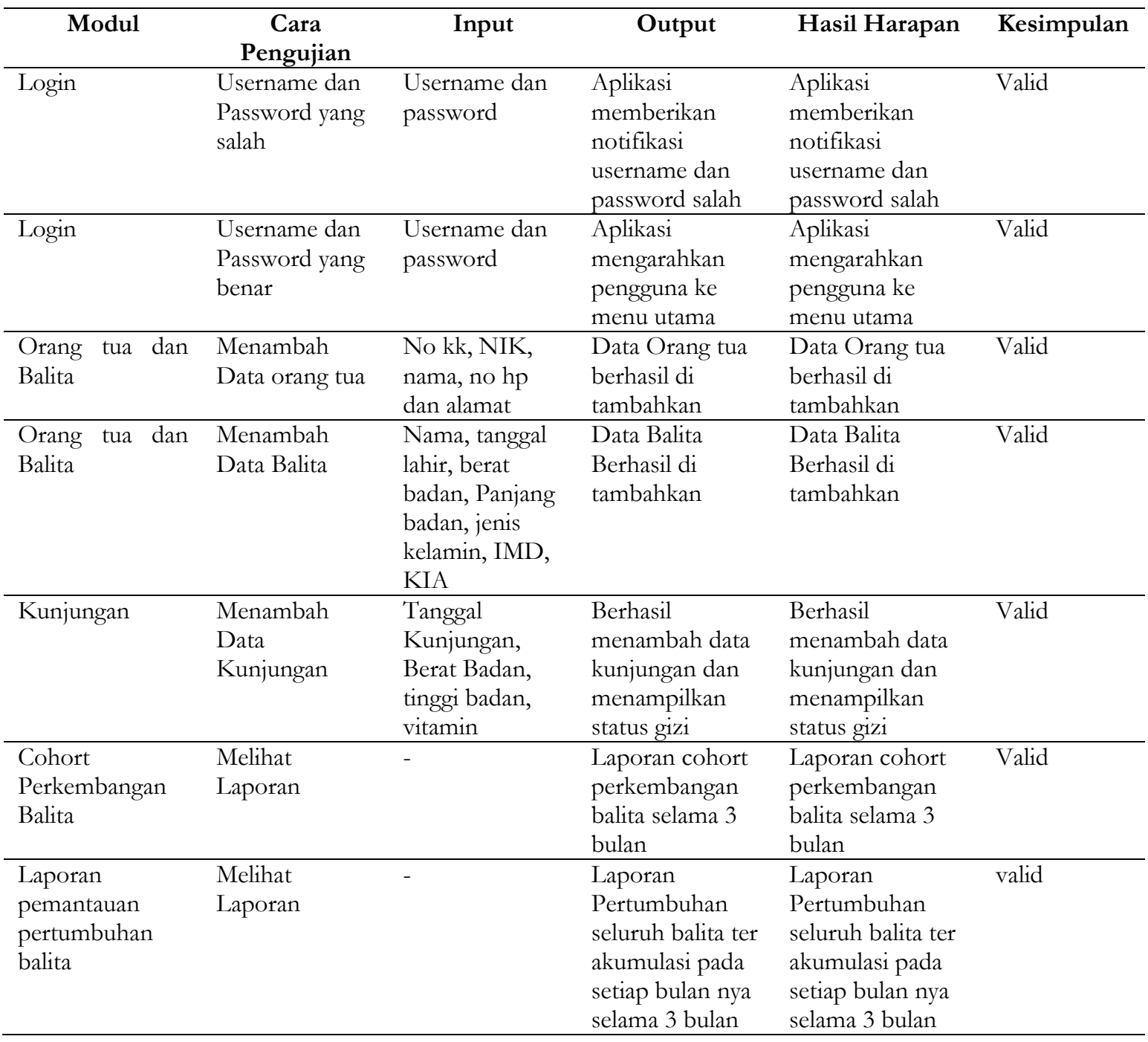

\section{Kesimpulan}

Perancangan sistem informasi posyandu berbasis kebutuhan kader dan petugas program gizi di UPTD Puskesmas II Dinas Kesehatan Denpasar Timur dapat menjadi salah satu solusi untuk mengatasi kendala dalam pencatatan pelaporan secara manual, mengurangi frekuensi rekapitulasi data, memotong alur dan mempercepat waktu pelaporan dan analisis data kegiatan posyandu balita. Oleh karena itu perlu disarankan kepada pihak puskesmas dan kader untuk bisa menggunakan sistem informasi posyandu ini secara berkelanjutan dengan pendekatan pelatihan dan pendampingan mengenai sistem informasi posyandu. Sementara untuk pengembangan program perlu ditambahkan fitur grafik KMS balita. 


\section{Ucapan Terimakasih}

Ucapan terimakasih disampaikan kepada LP2M FIIK UNBI yang memberikan pendanaan terhadap penelitian serta Kepala UPTD Puskesmas II Dinas Kesehatan Denpasar Timur yang telah memberikan ijin penelitian ini.

\section{Daftar Pustaka}

1. Bappenas. Rencana Pembangunan Jangka Menengah Nasional 2020-2024. Kementrian Perencanaan Pembangunan Nasional. Jakarta: Kementerian PPN/Bappenas; 2019.

2. Kemenkes RI. Ayo ke Posyandu Setiap Bulan. Jakarta: Kemenkes RI Pusat Promosi Kesehatan; 2012.

3. Sasmito GW. Penerapan Metode Waterfall Pada Desain Sistem Informasi Geografis Industri Kabupaten Tegal. J Inform Pengemb IT. 2017;2(1):6-12.

4. Kementerian Kesehatan RI. Peraturan Menteri Kesehatan Republik Indonesia Nomor 2 Tabun 2020 Tentang Standar Antropometri Anak. Indonesia; 2020 p. 1-89.

5. Kementerian Kesehatan RI. Peraturan Menteri Kesebatan Republik Indonesia Nomor 14 Tabun 2019 Tentang Pelaksanaan Teknis Surveilans Gizi. Indonesia; 2019 p. 1-81.

6. Arista D, Alit R, Mumpuni R. Penerapan Dynamic System Development Method Pada Sistem Informasi Posyandu Pagerwejo. J Inform dan Sist Inf. 2020;1(3):865-73.

7. $\quad$ M IS, Wijianto R. Pengembangan Aplikasi Pos Yandu Berbasis Web. J Evolusi. 2017;5(2):43-7.

8. Supriyanto A. Peran Teknologi Informasi Bagi Kader Posyandu Dalam Kegiatan Pendataan KIA. In: Prosiding Semnasvoktek [Internet]. Denpasar; 2017. p. 360-5. Available from: http://eproceeding.undiksha.ac.id/index.php/semnasvoktek/article/view/706

9. Kristania YM, Yulianti FD. Perancangan Sistem Informasi Pelayanan Pada Posyandu Pepaya Purwokerto. J Evolusi. 2019;7(1):68-75.

10. Egeten AEJ, Damanik SA, Agustina I, Panggabean M. Perancangan Sistem Informasi Posyandu Berbasis Web Pada Yayasan Kalyanamitra Di Jakarta Timur Untuk Mendukung Program Bidang Pendampingan Komunitas. J MATRIK J Manajemen, Tek Inform dan Rekayasa Komput. 2019;18(2):330-8.

11. Kamilah F. Analisa dan Perancangan Sistem Informasi Posyandu Berbasis Web (Studi Kasus: Posyandu Mandala 2). J Sist Inf dan E-bus. 2020;2(4):479-95.

12. Musliani M, Wati L, Mawarni S. Aplikasi Pengolahan Data Posyandu. INOVTEK Polbeng - Seri Inform. 2017;2(1):41.

13. Amrozi Y. Analisis Perancangan Sistem Informasi Pendataan Balita Posyandu Dablia. JUST IT J Sist Informasi, Teknol Inform dan Komput. 2019;10(1):13-7.

14. Martono M, Supriyanti D, Firmansyah I. Rancang Bangun Website Posyandu Kasib Ibu Kelurahan Kelapa Indah Tangerang. J CERITA. 2020;6(2):216-28.

15. Indriawati W, Aruan MC, Parwatiningtyas D. Perancangan Sistem Informasi Pendataan Pada Posyandu RW 04 Cipinang Muara Berbasis Java. In: Seminar Nasional Riset dan Teknologi (SEMNAS RISTEK). Jakarta; 2021. p. 1183-8.

16. Prigianata MM. Sistem Informasi Posyandu Guna Mempermudah Pencatatan Pemeriksaan Berbasis Web. JIntech. 2013;1(1).

17. Kusumadewi S, Kurniawan R, Wahyuningsih H. Implementasi Sistem Informasi Posyandu Berbasis Web dan Android di Desa Bimomartani. JPPM (Jurnal Pengabdi dan Pemberdaya Masyarakat). 2019;3(2):351-9.

18. Mengkasrinal T, Maiyana E, Silvia S. Perancangan Sistem Informasi Posyandu Lasi Kec Canduang Kab Agam Sumbar Berbasis Web Android. In: Prosiding SISFOTEK [Internet]. Padang; 2017. p. 14653. Available from: http://seminar.iaii.or.id/index.php/SISFOTEK/article/view/70 